\title{
Ukrainian Social Changes in the Novel Twelve Circles by Yurii Andrukhovych
}

\author{
Janja Vollmaier Lubej \\ Department of Slavonic Studies, Faculty of Philological and Cultural Studies, University of Vienna, Austria
}

Copyright(C2018 by authors, all rights reserved. Authors agree that this article remains permanently open access under the terms of the Creative Commons Attribution License 4.0 International License

\begin{abstract}
The article presents social changes in Ukraine after its secession from the Soviet Union and in the time of the new, capitalist era as shown in the novel Twelve Cricles by the Ukrainian writer Yurii Andrukhovych. The article deals with the economic image of the post-Soviet Ukraine and presents some of the key consequences we can see in the mentioned novel. These are labour migrations, abandoned children, prostitution and alcohol addiction.
\end{abstract}

Keywords Post-Soviet Ukraine, Twelve Cricles, Yurii Andrukhovych, Social Changes, Ukraine

\section{Introduction: Post-Soviet Ukraine Pluridisciplinary Perspectives.}

When the Soviet Union collapsed in 1991 and its former socialist republic Ukraine chose a path to democracy instead of totalitarian Stalinist-Leninist ideology, it was subject to many political, economic, cultural and social changes. The set-up or building of a new social community was a complicated process. The collapse of the Soviet Union took place in a peaceful manner, but the formation of a new, independent country was far from easy. At the time of the declaration of Ukrainian independence, there were great expectations for the future in the independent country which was supposed to become a rich democracy with a free market and a full member of the European and Euro-Atlantic community, but these expectations have not been fulfilled yet [1]. The modern Ukraine is in the process of approximation to the European Union and is also drifting away from it (Yanukovych's refusal of signing the treaty between the European Union and Ukraine which caused Euromaidan); even today, twenty-five years after independence, we cannot write about concrete shifts ahead. The country was unable to sign the treaty with the European Union about a visa-free regime because of unmet requirements.

After 1991, Ukraine has been struggling with great economic crisis which was also a consequence of industrialization and uncompetitive conditions [1]; the country which was once the leader in agriculture is now facing unused farmland, the coal mines which once made profit, are now making loss. Many see the causes for the poor financial situation in the country after independence also in the shuffling of politicians for power or in the switch of elites $[1,2,3]$. At the same time, the country has seen many oligarchs remain in positions; these used the time of privatization and now control the economy because of suspiciously gained wealth and have an outstanding role in politics as well [4]. The result of this can still be seen today, we can observe a great abyss between the rich and the poor, where everything goes and the law is broken on the one hand, and freedom is deprived on the other. Political instability in the newly established country made it impossible to set up functional administrative institutions [1] and due to the fact that any compliance with the law evaporated, the Ukrainian economic environment was not encouraging for competition, investment and development [1]. The country also faces great risk of corruption and grey economy which are still two of the greatest Ukrainian problems. According to various sources, grey economy in Ukraine today reaches from 20 to $50 \%$ [5]. According to estimates of many international experts, money drain as a consequence of corruption exceeds 10 trillion dollars annually [5]. Money is also lost because of salary payments made in envelopes, the amount of such payments is supposed to amount to 200 trillion of UAH [5]. Furthermore, the Index of Economic Freedom estimates that Ukraine has one of the worst conditions for economic development between countries of the European Union and former countries of the Soviet Union [5]. According to the Corruption Perceptions Index, the country was ranked 144th out of 177 countries in 2013 [5]. Some authors also describe corruption as endemic [6].

At the same time, Ukraine was unsuccessful in export and management of domestic economy [1]. Some see the processes of the Ukrainian market as the "monster of wild western capitalism, which enabled the few to become 
abnormally rich but pushed the majority into even deeper poverty" [3] Ukraine became a global periphery after the independence where the differences between the rich and poor only became bigger and deeper. The German magazine Der Spiegel from 1994 reads: "the past Soviet economic model was followed by an even more absurd one which does not even have a plan or market but is ruled by the laws of the jungle" [3].

Although Ukraine measured economic growth in the first seven years of the new millennium, this trend stopped because of the global economic crisis a year later [4]. It is shocking to see that Ukraine today is the second poorest European country, taking into account that the neighboring Poland, which is economically successful today, was at a comparable economic starting point in 1990: according to official data, the GDP of the former was 1,569 USD per capita, and the latter 1,693 USD; in 2012, the Ukrainian GDP was 3,866 USD, whereas the Polish was 12,707 USD [7]. At the same time, the post-Soviet individual found it hard to cope in the new society. In a way, one wanted to erase any Soviet traces of the past and collective memory, on the other hand one could not or did not want to easily accept the new forms of establishing the independent country. Vesna V. Godina concludes in her monograph Delusions of Post-Socialism (2014) with the help of the findings of anthropologists that individuals in new societies maintain the operations, standards, in other words what stems from the past and thus prevent the activities of the new post-Socialist institutions. They also frequently obstruct and block post-Socialist changes [8]. In post-Socialist societies, new institutions and practices did not take hold and exist in societies as a foreign object [8]. In 2005, most of the teachers from the city of Chernivtsi reported that the changes in the social sphere are for the worse, that the people were forced to adapt to new realities because of the loss of the former way of life. Many teachers stated that the new country has seen interpersonal relationships become more emotionally detached and cold [2].

Nevertheless, Ukraine, like other eastern countries, did not evade the implementation of capitalism. According to anthropologists [8], the post-Socialist societies saw the emergence of a new type of capitalism called neo-capitalism which is characterized by "processing the fundamental capitalist principles into new ones which are even more non-egalitarian than the western model" [8]. Global peripheries were established which are a result of the dependence of Eastern Europe from global capital where unfair money making on the one and increasing poverty on the other hand is an indisputable fact and a great overall globalization problem which Ukraine was also unable to evade.

The consequence of the problems exposed above the post-Soviet Ukraine is facing, are workforce and economic migrations and a decline of Ukrainian population, abandoned children, a rise in alcoholism and the feminization of poverty which is reflected in prostitution.

Ukraine is facing a decline in life expectancy and one of the important reasons is also alcohol. Official data shows that the use of alcohol per litre of pure alcohol per capita is slightly over the European average and that it is declining (14.3 in the period of 2003-2005, 13.9 in the period of 2008-2010, whereas the European average is 11.9 or 10.9) [10], but we must emphasize that the data is not realistic. Experts namely warn about the misleading data and that the level of alcohol addiction is actually rising [11]. Since independence, Ukraine has been facing mass emigration and is the country with one of the biggest diaspora in the world with 5-6 million of people. In 1991-2015, the Ukrainian population fell by nine million (from 52 to 42.9 million) [12]. Modern Ukraine is facing numerous workforce migrations, there is a visible increase in migrations to Poland, especially because of linguistic and cultural similarities as well as easy and free bureaucratic procedures [9]. Many Ukrainians also work in other European countries i.e. The Czech Republic, Italy, Spain, the Netherlands, etc. These are mainly low paid jobs with unregulated conditions. According to data from 2012, 3.4\% of the population of Ukraine are work migrants and $25 \%$ of them work abroad illegally [14]. The consequences of work migrations are abandoned children which had to be raised by grandparents or other relatives and friends. It is clear that the absence of one or both parents causes great trauma and tough life trials. The first separation of parent and child in Ukraine lasts from two to five years. It is also sad that work migrations are becoming more and more permanent and so is the bond between all really and symbolically distant children and parents [14].

Some countries of the former Soviet Union including Ukraine became the central countries in prostitution [15]. Women from the Ukraine and Russia are the most popular in the sex industry. Between 1991 and 1998, 500,000 Ukrainian women went into prostitution [15]. In 1998, a criminal investigation in Germany found that $87.5 \%$ of prostitutes in Germany came from Eastern Europe, $14 \%$ of which were from Ukraine [15]. Besides basic causes (unemployment and low wages), the increase of prostitution can also be attributed to it being tolerated in Ukrainian reality in the feminization of poverty and the normalization of this polemic. Today, individual prostitution in Ukraine is not an offence. It is tragic that the victims of an inoperative state and its system are also children who are, like women, forced into human trafficking.

\section{The Reflection of Ukrainian Post-Soviet Reality in Literal Works of Yurii Andrukhovych}

Yurii Andrukhovych (1960) is a prominent Ukrainian post-modern writer, poet and essayist who has received 
numerous prestigious awards for his work at home and abroad. His novels have been translated into numerous languages and have received the greatest critical acclaim, they describe post-totalitarian, post-Soviet Ukraine and the position of its individual and/or society. Andrukhovych's great creative topic is "the issue of the individual's and/or the collective's identity in the transitional and post-Soviet era" [16] his novels aspire to overcome the imperialistic past (ibid.). His characters are determined by a traumatised past which they are not able to escape. Andrukhovych's novels Recreations (1992), The Moscoviad, (1993), Perversion (1996) and Twelve Circles (2003) deal with the imperialistic past, life in an empire and the consequences for the individual and society. The author presents the individual's destiny which is still pinned to the remnants of totalitarianism in the post-independence period and is thus unable to come back to life. His narrations lean on trauma and hopelessness for the individual as well as the society. The work of Yurii Andrukhovych dedicates a special place to (Non) Europe and the position of Ukraine in it and emphasizes the disadvantaged position of Ukraine in Europe. The author's last novel Twelve Circles (2003) closes in on the question of Ukraine's image in Europe and the remnants of the totalitarian past via a foreigner, an Austrian Joseph Zumbrunnen who is as objective as possible in his observations; the novel also thematises life in the era of capitalism and consumer society and takes its consequences into account.

When the novel Twelve Circles, which can be read as a critique of Ukrainian society, was published in 2003, some blamed the author of giving a contemptuous portrait of Ukraine and even claimed he was a paid agent of the West. But Andrukhovych is a writer whose literary texts are critical towards the Ukrainian situation and set it an objective mirror; the issues in the essays and novels are not portrayed one-sidedly, they are illuminated from a wider cultural and social viewpoint.

The novel portrays the Ukrainian reality and the evil-filled past and present from several perspectives. Twelve Circles was written in a time when Ukraine seemed to move away from Soviet subordination and began to politically and culturally draw nearer to the European community and its ideas. But the remnants of the ever-present totalitarianism and its intermingling with the new capitalistic and consumerist era can still be detected. It seems the cycle of the history of evil continues into the new, independent Ukrainian reality. The novel presents the individual and society in this modified time and space and the consequences we are witnessing today. This is a society without values, community, with massive emigrations to neighboring countries in search of a better life, a society which does not respect the Roma and does not care for art. Instead of the above mentioned, we see an establishment of superficiality, quick and unfair money-making, circumvention of the system, lying, etc. Yurii Andrukhovych is a post-modern Ukrainian writer who entered the literary world as a poet. The novel Twelve Circles features three main characters: an Ukrainian writer-drunkard Artur Pepa, his wife, a translator and Germanist Roma Voronich as femme fatale and responsible mother and an Austrian photographer Karl Joseph Zumbrunnen who does not understand Ukrainian; he substitutes his disadvantage with photography and uses his critical eye to literally and symbolically paint the Ukrainian harsh reality of slow trains, visas, customs officers, power cuts and especially the sad fate of the country which had potential but did not know how or could not use it. There is a dangerous love triangle between Artur, Roma and Karl Joseph, which is fatal for the latter. All three arrive with other guests in the Carpathian Mountains in the »Tavern On The Moon« to celebrate the memory of the forgotten Ukrainian poet from the 1930s Bohdan-Ihor Antonych, whom the author dedicated a literalized fictive biography featuring his poems, testimonials, memories, half-truths, deceits and especially the attitude of the elite of that time towards the poet's life and work. Among central characters, the novel also features Roma's daughter Kolya, a Professor Doktor and expert on Antonych's poetry, two flirts and main characters of the marketing video for a liquor concoction called Vartsabych's Balsam, Lilya and Marlena, the director Volshebnik and tycoon and oligarch Vartsabych. The narration does not feature a lot of action but this is no novelty for Andrukhovych's Romanesque opus. As far as the genre is concerned, the novel is a socially-critical criminal and detective novel. Yurii Andrukhovych creates a dark, hopeless and grotesque atmosphere in his novels which dangerously repeat in modified versions in historical time and space. The novel Twelve Circles is the same, its title itself hints at the symbolism of the cycle as an eternal repetition and returning to the beginning.

\section{Analysis}

The analysis includes the premise that the novel Twelve Circles offers a multi-perspective image of Ukrainian social changes which can be seen in the post-totalitarian and post-Soviet reality. The analysis also wants to present an image of Ukrainian capitalist and consumer reality as it is presented in the chosen novel.

The novel is set in the 1990s, in a time when Ukraine becomes an independent country. Economic experts from the West at that time estimated that it could develop into a stable country with a competitive economy. Furthermore, Ukrainian economy presented an enormous economic and industrial potential among former countries of the Soviet Union. After independence, the deterioration of industry and agriculture sped up, the banking system collapsed, which led to loss of employment and as a result, economic migration.

The work migrants in the novel are Lilya and Marlena 
who represent another Ukrainian reality, i.e. the objectification of women. Lilya was promised a job of a dancer in the Czech Republic, Marlena occasionally dances in a bar in Poland whereas their classmate Leska sits in a payable toilet in Venice and waits for voluntary contributions from the customers. Thus, the feminisation of poverty is shown through two flirts and unintelligent women and at first glance maybe the voluntary choice of prostitution. In the novel, they are filming the advertisement for Vartsabych's balsam with revealing clothing and are portrayed as an object of desire. Their simple conversation testifies they do not speak about their emotions, experiences and past memories, but about how you can make money. They are displayed as consumers who must take care of their body to be desirable and come close to the ideal of beauty. Lilya and Marlena only differ in their appearance and are contemporaries formed by television, magazines and the Soviet way of life. They are girls who think about nothing and normalize prostitution and objectification of women in the modern society. Their salary is meagre and does not enable them a decent living, they are victims of modern sexual slavery. The novel also portrays the changed attitude towards the body, detabuization of sexuality and free choice of sexuality are emphasized. Roma cheats on her husband Artur and thus violates the so-called traditional values and destabilizes the so-called traditional marriage. Roma, Marlena and Lilya also show the influence of the global market on the perception of one's own body as the object of desire and commercialization.

The perception of work migrations as a falsely understood hope for a better tomorrow is portrayed in the novel through the eyes of a stranger who portrays Ukrainian reality with the utmost sharpness through his letters to his Austrian friends. The Austrian Karl Joseph Zumbrunnen, who has an affair with Roma, tries to convince her to leave her country and go anywhere else with him; these pleads and promises portray him as a wealthy western egoist who forgot at one point that Roma has a daughter. There is a turnaround, his lover turns him down just for this fact. She does not want to become a trans-national mother who takes care of her child from a distance, to distance herself from it and give it into care.

Zummbrunnen's letters testify Ukraine has not distanced itself from the former regime, he writes about unsolved accidents, suicides, disappearances of politicians, news reporters, etc. It is a time when new repression, totalitarianism and lack of freedom of expression are being established and all this is being noticed by a stranger and not the locals themselves. Karl Joseph Zumbrunnen frequently returns to Ukraine as a foreigner; his first visit was at the beginning of the 1990s when it was a completely new and independent country. He describes his findings to his friends in a monologic and descriptive manner. He writes that the independent country lost its chance in 1994:

"This country had a great chance for change - to flash jump from continuous distortion and oligophrenic despair to at least a normal state. But it turns out that the number of those who do not want this shift in the country itself and do not want its existence as such at all, significantly exceeds all permissible limits" [17].

It seems that among all characters only Zumbrunnen as foreigner can seriously and deeply analyze and write about the Ukrainian reality. His letters inform us that Ukraine is plagued by numerous problems in establishing a new state which is facing the remnants of the past. At one point he emphasizes that living in the newly established country is dangerous for some, points out wire taps, unresolved murders, the increase in criminality and especially the golden age of the black market with firearms. He ironically names the current totalitarianism as a creeping one, it is still emerging in an independent state but in a different, modified version. He finds people are afraid of living in such a state and records the unresponsiveness of the authorities with the following aphorism: "The police state is where the police are omnipotent for honest citizens and impotent against criminals" [17].

Twelve Circles also portrays a changed role of art/artists in society and changed relationships among individuals where both cues strive for fast and incomprehensible emptying of essence. The novel thus holds the changed image of art in a modern, post-modern society where it is intertwined with radical secularization, differentiation and ideological fragmentation in a wider context [18]. Artur Pepa is a quasi-writer who thinks all the time about what to write but can only put his thoughts into words with difficulty. He was also subject to censorship when he wanted to re-evaluate the literary canon with his book and to a public lynch by the burning of a book. He wants to write a best-seller; he wants to please but by doing so he is approaching the field of triviality and subordination which the modern profitable social reality dictates. Artur is portrayed through his stupid deeds (especially when he wants to pay revenge to his wife's lover Zumbrunnen), he is also determined by mediocre and empty dialogue. He has alcohol problems and consequently serious heart problems, tachycardia to be precise. An amplified quasi-artist in the novel is the director Volshebnik who reads and chooses stupefying scenarios for the advertisement, they all hint at sexuality and erotica. The only thing important for him is social status. The novel emphasizes manipulative motives which would enable the twisting of recent literary history, the poems of Bohdan-Ihor Antonych who was writing at the beginning of the 1930s and whom Andrukhovych dedicated the sixth chapter of the novel; his poems are logically embedded into the novel, in some places they are presented in a simplified manner, stupefied, with the goal to popularize the poet. Volshebnik's commonness is clearly portrayed in his conversations with the others where it is obvious that he is not capable of talking without fillers, interruptions, his speech is not finished and his vocabulary is on a very low level. He sold art because of 
commercialization, following trends and his own profit. The only hope for art as well as life, which the novel possibly inspires, is Roma's daughter Kolya, a young girl who understands the meaning of Antonych's twelve cycles of spring and is a pleasant partner for conversation.

It seems that the grotesque emptiness is amplified by the world which emphasizes empty phrases, quick, uncritical satisfaction and the absence of self-control. Andrey Kurkov, a distinguished Ukrainian writer, also sees the changed role of art in the post-Soviet reality which made it possible in the independent state to "publish everything; but literature lost its role" [19]. The novel Twelve Circles also indirectly points at this problem and at the same time emphasizes censorship in virtual freedom. One of Artur Pepa's books was namely burned because of his views on literature.

It was mentioned that the independent Ukraine saw the establishment of an environment which favored the increase of oligarchs who control the economy, politics, etc. In the novel, the tycoon and oligarch is presented in the form of Vartsabych, the owner of a resort where the main characters have their lodgings, a car junk yard and a booze joint. He is portrayed as superhuman who never shows himself, communicates with the characters indirectly and is allowed everything; he also has direct power in all pores of life.

Alcoholism is a big problem in today's Ukraine, the consequences are not only the collapse of the individual, the destruction of the family and broader society, but also the disappearance of many Ukrainian villages. Drinking is a way of life for many Ukrainians, because spirits are affordable and can be bought everywhere. The novel portrays partying and drowning the dissatisfaction in alcohol; the characters generally drink a lot, especially Artur Pepa.

In Twelve Circles, a large car junk yard also appears which is owned by the aforementioned Vartsabych, this literary space is a metaphorical representation of the finality of yesterday's world and/or the beginning of something new. Arhur Pepa and Roma find themselves there in an abandoned car and think about the future of their love and the meaningfulness of the space-time in which they are trapped. The novel emphasizes the neglect and filthiness of Ukrainian rivers and streams in many places with which the author hints at the real problem the country is facing. It is significant, that there was 19.7 trillion cubic meters of waste water in 1990 [20] Yurii Andrukhovych is also an author of numerous essay collections where he portrays the mentioned topics in the light of European ignorance towards Ukraine and its (non)approximation to Europe. The in the essay collection Disorientation on Location [21] he emerges himself into various topics, especially descriptively relating to extra-literal topics, Ukraine, Lviv, the Hapsburg area with all its linguistic and cultural colorfulness, he is also interested in the image of art and the artist where he turns to the poet Bohdan-Ihor
Antonych several times and whom he devotes a special place in the novel Twelve Circles.

\section{Conclusions}

The novel Twelve Circles is set in the 1990s at the time of Ukrainian independence and portrays life in the post-socialist state. It seems the individual and broader society are still embedded in the past and tradition despite the virtual freedom in the newly established country, thus there are no eventual changes for the better. What is more, life directly after the independence in this country is not pleasant and does not offer dignity; as a result, numerous negative effects for society appear such as migrations, abandoned children, the increase of prostitution, the embedded problem of alcoholism and modified versions of the old system as seen by the foreigner Karl Joseph Zumbrunnen; the country is also already facing the consequences of Capitalism.

The all-knowing narrator displays a multi-perspective, unavoidable and sad destiny of the country which had potential but did not know how to use it.

\section{Acknowledgements}

I would like to mention that this article was published in publication Social and political processes in modern Slavic cultures, languages and literatures [23].

\section{REFERENCES}

[1] P. Sutela. The Underachiever: Ukraine's Economy Since 1991. 2012. Onlineavailablehttp://carnegieendowment.org/ 2012/03/08/underachiever-ukraine-s-economy-since-1991-p ub-47451

[2] B. Kutsyuruba. Education in the Period of Post-Soviet Transition in Ukraine. Democracy. A journal od ideas. Winter Issue, 287-309, 2011. Online available fromhttps:// www2.gwu.edu/ ieresgwu/assets/docs/demokratizatsiya $\% 2$ 0archive/GWASHU DEMO 19 3/J57410H66R1H7404/J5 7410H66R1H7404.pdf

[3] Die Ukraine - Land mit zwei Gesichtern. 2014. Online available fromhttp://www.mdr.de/damals/archiv/ukraine194 .html

[4] Die unabhängige Ukraine. 2015. Bundeszentrale für politische Bildung. Online available fromhttp://www.bpb.d e/izpb/209819/die-unabhaengige-ukraine

[5] A. Bochi, V. Povoroznyk. Shadow economy in Ukraine: causes and solutions, International Centre for Policy Studies, $2014,1-7$.

[6] L. Janovič. Children Left Behind: The Impact of Labor Migration in Moldova and Ukraine. 2015. Online available 
from http://www.migrationpolicy.org/article/children-left-be hind-impact-labor-migration-moldova-and-ukraine

[7] R. Fisher. Ukraine vs Poland by GDP 1990-2012, 2014. Online available fromHttp://www.reinisfischer.com/ukraine -vs-poland-gdp-1990-2012.

[8] V. V. Godina. Drugi pogled: uvedba antropološke perspektive. V. V. Godina. Zablode postsocializma, Beletrina, Ljubljana, 2014, 100-180.

[9] M. Jaroszewicz. The migration of Ukrainians in times od crisis. Centre for Eastern Studies No. 187, 1-8, 2015. Online available from http://www.osw.waw.pl/sites/default/files/co mmentary_187.pdf

[10] Ukraine: Alcohol Comsumption. Online available fromhttp: //www.who.int/substance_abuse/publications/global_alcoho 1_report/profiles/ukr.pdf

[11] A. V. Samokhvalov, V. S. Pidkorytov, I. V. Linskiy, O. I. Minko, O. O. Minko, J. Rehm, S. Popova. Alcohol use and addiction services in Ukraine. International Psychiatry, Vol. 6, No. 1, 5-7, 2009. Online availablefromhttp://www.psych iatry.ua/eng/eng049.htm

[12] F. Düvel, I. Lapšina. The EuroMaidan Protests, Corruption, and War in Ukraine: Migration Trends and Ambitions. Online available from http://www.migrationpolicy.org/articl e/euromaidan-protests-corruption-and-war-ukraine-migratio n-trends-and-ambitions

[13] A. Portnov. Postsowjetische Hybridität und "Eurorevolution" in der Ukraine - Essay. Online availablefromhttp://www.bpb.de/apuz/194814/postsowjetis che-hybriditaet-und-eurorevolution? $\mathrm{p}=0$

[14] O. Malinovska. Caught Between East and West, Ukraine Struggles with Its Migration Policy. 2006. Online available from http://www.migrationpolicy.org/article/caught-betwee n-east-and-west-ukraine-struggles-its-migration-policy

[15] D.M. Hughes, T. Denisova. Trafficking in Women From Ukraine. U. S. Department of Justice. 2003.

[16] J. Vollmaier Lubej, V temni noči opotekajoči se pijanec. J. Andruhovič. Dvanajst krogov, Cankarjeva založba, Ljubljana, 209-220, 2016.

[17] J. Andruhovič. Dvanajst krogov, Cankarjeva založba, Ljubljana, 2016. Ю. Андрухович. Дванадцять обручів, Критика, Київ, 2003.

[18] A. Zupan Sosič. Trivialnost. Slavistična revija Vol. 59, No. 2, 147-160, 2011.

[19] M. Dović. Profesionalizacija slovenskega literarnega proizvajalca. Nekaj uvodnih opažanj. Primerjalna književnost, VOL. 29, No. 2, 125-140, 2006.

[20] V. Boreyko. The environment: Pollution plagues large areas of Ukraine, The Ukrainian Weekly, Vol. 6, No. LXI, 1993. Online available from http://www.ukrweekly.com/old/archi ve/1993/069303.shtml

[21] J. Andruhovič. Дезорієнтація на місцевості, Лілея-НВ, Івано-Франківськ, 1999.

[22] J. Vollmaier Lubej: Ukrajinske družbene spremembe v romanu Jurija Andruhoviča. A. Čuš, M. Potocco, L.Rezoničnik, N. Zavašnik, Družbeni in politični procesi v sodobnih slovanskih kulturah, jezikih in literaturah. Mednarodna znanstvena konferenca mladih humanistov, e-zbornik. Založba Univerze na Primorskem. 2018. 